\title{
Aeromicrobium marinum sp. nov., an abundant pelagic bacterium isolated from the German Wadden Sea
}

Correspondence

Thorsten Brinkhoff

t.brinkhoff@icbm.de

\author{
Alke Bruns, Helge Philipp, Heribert Cypionka and Thorsten Brinkhoff
}

Institut für Chemie und Biologie des Meeres, Fakultät für Mathematik und

Naturwissenschaften, CvO Universität Oldenburg, PO Box 2503, D-26111 Oldenburg, Germany
The presence of Gram-positive bacteria as indigenous members of marine bacterial communities has been recognized only relatively recently. Their ubiquitous distribution in marine habitats was demonstrated by clone libraries (Fuhrman et al., 1993; Rappé et al., 1997; Urakawa et al., 1999) or by hybridization with 16S rRNA genus-specific probes (Moran et al., 1995). The clones recovered from bacterioplankton of the Sargasso Sea and the Pacific Ocean so far form a phylogenetically coherent clade (Rappé et al., 1997) within the newly proposed phylum 'Actinobacteria' (Garrity \& Holt, 2001) and they are distantly related to their nearest cultivated relatives (Rappé et al., 1999). Recent studies even suggest that marine Grampositive bacteria represent a large fraction of the culturable heterotrophs from sea water, marine sediments, algae and invertebrates (Jensen \& Fenical, 1995; Ortigosa et al., 1997; Mincer et al., 2002) and most of them require sea water for

Published online ahead of print on 23 May 2003 as DOI 10.1099/ ijs.0.02735-0.

Abbreviations: DAPI, 4',6-diamidino-2-phenylindole; MPN, mostprobable-number.

The GenBank accession number of the 16S rRNA gene sequence of Aeromicrobium marinum $\mathrm{T}_{2}{ }^{\mathrm{T}}$ is $\mathrm{AY} 166703$.

A comparison of the cellular fatty acids of $A$. marinum with those of related taxa is available in IJSEM Online. growth. This is an important trait to characterize the origin of Gram-positive bacteria from marine environments. There is an ongoing debate whether Gram-positive bacteria, especially those which were isolated from near-shore habitats, are an indigenous component of the marine bacterial community or whether they were washed in from terrestrial systems (Jensen et al., 1991; Takizawa et al., 1993; Bull et al., 2000). The wash-in hypothesis is based on different studies which demonstrated a high degree of salt tolerance of many terrestrial streptomycetes (Okazaki \& Okami, 1976) and showed that the number of actinomycetes in marine habitats decreases with increasing distance from land (Goodfellow \& Haynes, 1984). Despite the evidence supporting growth of actinobacterial species in marine environments (Ortigosa et al., 1997; Mincer et al., 2002), only a few marine species, for example, Rhodococcus marinonascens (Helmke \& Weyland, 1984), Dietzia maris (Rainey et al., 1995) and Microbacterium maritypicum (Takeuchi \& Hatano, 1998), have been characterized in detail. Thus, the ecological role of marine Gram-positive bacteria remains still unexplained. We isolated and characterized an abundant indigenous Gram-positive bacterium from surface waters of the German Wadden Sea. This organism is affiliated with the genus Aeromicrobium and is the first marine representative of the family Nocardioidaceae within the order Actinomycetales. 
Aeromicrobium erythreum DSM $8599^{\mathrm{T}}$ and Aeromicrobium fastidiosum DSM $10552^{\mathrm{T}}$ were obtained from the DSMZ (Deutsche Sammlung von Mikroorganismen und Zellkulturen, Braunschweig, Germany) and were cultured as recommended by the supplier. Strain $\mathrm{T}^{\mathrm{T}}$ was isolated from the highest positive dilution $\left(10^{-4}\right)$ of a most-probable-number (MPN) series ( $1 \mathrm{ml}$ inoculum added to $9 \mathrm{ml}$ medium). Marine broth (MB; Difco Laboratories) was used as medium and was inoculated with Wadden Sea surface water sampled near the village of Neuharlingersiel $3 \mathrm{~h}$ before high tide. Incubation of the MPN series was carried out at $28^{\circ} \mathrm{C}$ for 30 days. Total bacterial numbers in the water sample were determined by $4^{\prime}, 6$-diamidino-2-phenylindole (DAPI) staining according to Crump et al. (1998). Isolation and subcultivation were performed in $\mathrm{MB}$ or on marine agar (MA 2216; Difco Laboratories) at $28^{\circ} \mathrm{C}$. For some phenotypic characterizations, the organism was cultured in artificial sea water (ASW) modified after Levring (1946) consisting of (per litre distilled water): $23.6 \mathrm{~g} \mathrm{NaCl}$; $0.64 \mathrm{~g} \mathrm{KCl} ; 4.53 \mathrm{~g} \mathrm{MgCl}_{2} .6 \mathrm{H}_{2} \mathrm{O} ; 5.94 \mathrm{~g} \mathrm{MgSO}_{4} .7 \mathrm{H}_{2} \mathrm{O}$; $1.3 \mathrm{~g} \mathrm{CaCl}_{2} \cdot 2 \mathrm{H}_{2} \mathrm{O} ; 10 \mathrm{mg} \mathrm{Na}_{2} \mathrm{PO}_{4} \cdot 2 \mathrm{H}_{2} \mathrm{O} ; 2 \cdot 1 \mathrm{mg} \mathrm{NH}_{4} \mathrm{NO}_{3}$. To avoid precipitation, the $\mathrm{CaCl}_{2}$ was sterilized separately. The ASW medium contained as source of carbon $0.3 \%(\mathrm{w} / \mathrm{v})$ yeast extract, $0.6 \%$ peptone and $0.3 \%$ glucose (denoted as
ASW/YPG). For minimal media containing only defined carbon sources (e.g. mannitol and amino acids), $10 \mathrm{ml}$ of a 10 vitamin solution (Balch et al., 1979) and $1 \mathrm{ml}$ of trace element solution (Widdel \& Bak, 1992) were additionally supplied per litre of ASW. All incubations for the characterization experiments were carried out at $20-25^{\circ} \mathrm{C}$ for 1-2 weeks. Morphological features were investigated with cells grown on MA or in MB. Colony morphology was studied using a Zeiss Axiolab microscope. Transmission electron microscopy was carried out with negatively stained cells (Cole \& Popkin, 1981) using a transmission electron microscope 109 (Zeiss). Motility was checked microscopically. The ability to grow with different carbon sources was analysed in ASW supplemented with $2-5 \mathrm{mM}$ of the tested carbon source. The temperature range for growth was determined in ASW/YPG between 4 and $55^{\circ} \mathrm{C}$. The $\mathrm{pH}$ range $(4 \cdot 5-10 \cdot 5)$ was tested in a minimal medium (ASW) containing $5 \mathrm{mM}$ mannitol. Growth was determined by an increase in turbidity. Gram staining, catalase and oxidase tests were performed as described by Smibert \& Krieg (1994). Salinity range was determined using ASW/YPG as basis medium. Exoenzyme activities (amylase by starch hydrolysis, caseinase by casein hydrolysis, chitinase by chitin hydrolysis and cellulase by hydrolysis of cellulose) were

Table 1. Phenotypic properties that differentiate Aeromicrobium marinum $\mathrm{T}^{\top}$ from related taxa

+ , Positive reaction or growth; -, negative reaction or no growth; ND, no data available.

\begin{tabular}{|c|c|c|c|c|c|}
\hline Characteristic & A. marinum $\mathrm{T}^{\mathrm{T}}$ & $\begin{array}{l}\text { A. erythreum } \\
\text { DSM } 8599^{\mathrm{T}}\end{array}$ & $\begin{array}{l}\text { A. fastidiosum } \\
\text { DSM } 10552^{\mathrm{T}}\end{array}$ & $\begin{array}{c}\text { N. albus ATCC } \\
27980^{\mathrm{T}}\end{array}$ & $\begin{array}{c}\text { K. sandramycini } \\
\text { ATCC } 39419^{\mathrm{T}}\end{array}$ \\
\hline Cell morphology & Rods & Irregular rods, cocci & Rods, cocci & Hyphae & Hyphae \\
\hline Cell size $(\mu \mathrm{m})$ & $0 \cdot 7-1 \cdot 3 \times 0 \cdot 3-0 \cdot 5$ & $0 \cdot 5 \times 0 \cdot 5-1 \cdot 2$ & ND & $0.5-1 \cdot 0$ in diameter & ND \\
\hline Aerial mycelium & - & - & ND & + & + \\
\hline \multicolumn{6}{|l|}{ Growth on: } \\
\hline Glycerine & - & + & + & + & + \\
\hline Glucose & - & + & ND & + & + \\
\hline Arabinose & - & + & + & + & + \\
\hline Rhamnose & - & - & - & + & + \\
\hline Mannose & - & - & + & + & + \\
\hline Trehalose & + & + & ND & - & + \\
\hline Lactose & - & - & ND & + & + \\
\hline Mannitol & + & - & ND & + & + \\
\hline Alanine & - & ND & + & ND & ND \\
\hline \multicolumn{6}{|l|}{ Hydrolysis of: } \\
\hline Starch & - & + & + & + & + \\
\hline Cellulose & - & + & - & $\mathrm{ND}$ & ND \\
\hline Casein & - & + & + & + & + \\
\hline Optimum temperature for growth $\left({ }^{\circ} \mathrm{C}\right)$ & 25 & 35 & 25 & 28 & $20-37$ \\
\hline DNA G $+C$ content $(\mathrm{mol} \%)$ & $70 \cdot 6$ & $71-73$ & $71-72$ & $66 \cdot 5-68 \cdot 6$ & $68 \cdot 3$ \\
\hline Major menaquinone MK-9(H4) & + & + & + & - & + \\
\hline Isolated from & German Wadden Sea & Tropical soil & Herbage & Soil & Mexican soil \\
\hline Reference(s) & This study & $\begin{array}{c}\text { Miller et al. (1991); } \\
\text { Schumann et al. } \\
\text { (1997) }\end{array}$ & $\begin{array}{c}\text { Collins \& } \\
\text { Stackebrandt } \\
\text { (1989) }\end{array}$ & $\begin{array}{l}\text { Prauser (1989); } \\
\text { Park et al. (1999) }\end{array}$ & Park et al. (1999) \\
\hline
\end{tabular}


analysed on solidified ASW medium with $1.5 \%(\mathrm{w} / \mathrm{v})$ agarose and supplemented with $0.5 \%(\mathrm{w} / \mathrm{v})$ starch, $10 \%$ $(\mathrm{w} / \mathrm{v})$ skim milk powder, $0.5 \%(\mathrm{w} / \mathrm{v})$ chitin and $1.0 \%(\mathrm{w} / \mathrm{v})$ cellulose, respectively, as described previously (Smibert \& Krieg, 1994). Lipase activity was also studied on solidified ASW medium supplemented with $2 \%(\mathrm{v} / \mathrm{v})$ vegetable oil. After incubation at $20^{\circ} \mathrm{C}$, the colonies in Petri dishes were covered with a $0.5 \% \mathrm{CuSO}_{4}$ solution and incubated for $15 \mathrm{~min}$. The solution was discarded and a positive result was indicated by a bluish or green colour around the colonies. The ability to denitrify was determined in ASW/YPG as described previously (Smibert \& Krieg, 1994). The peptidoglycan was analysed by TLC on cellulose plates according to the method described by Rhuland et al. (1955) which was modified by Hasegawa et al. (1983). Menaquinones were determined by HPLC as described previously (Groth et al., 1996) and results were verified by electron ionization MS. Fatty acid analysis was carried out as described by Sass et al. (2002). Isolation of genomic DNA (Cashion et al., 1977) and determination of the G $+\mathrm{C}$ content by HPLC (Tamaoka \& Komagata, 1984; Mesbah et al., 1989) followed described procedures. DNA-DNA hybridization analysis was performed by using the renaturation method of De Ley et al. (1970) with the modifications of Escara \& Hutton (1980) and Huss et al. (1983). Renaturation rates were computed with the TRANSFER.BAS program by Jahnke (1992). The dotblot hybridization procedure was performed as described recently (Bruns et al., 2002). In brief, a digoxigenin (DIG)labelled probe (length $569 \mathrm{bp}$ ) for the detection of strain $\mathrm{T} 2^{\mathrm{T}}$ was generated from a PCR-amplified 16S rRNA gene fragment (position 341-907 according to Escherichia coli numbering; Brosius et al., 1981) of its genomic DNA. This probe was used to hybridize 16S rRNA gene fragments amplified from the complete natural bacterial community. For calibration, different amounts of genomic DNA of strain $\mathrm{T} 2{ }^{\mathrm{T}}$ were used for amplification, subsequently blotted and hybridized with this probe. Intensities of the hybridization signals of the natural community and of the calibration were used to estimate the proportion of DNA from strain $\mathrm{T} 2{ }^{\mathrm{T}}$ in the community DNA. Preferential amplification of the 16S rRNA gene of strain $\mathrm{T} 2^{\mathrm{T}}$ was tested by adding different concentrations of genomic DNA of strain $\mathrm{T}^{\mathrm{T}}$ to $10 \mathrm{ng}$ of the community DNA prior to PCR amplification and hybridization. Cross-hybridization was tested by using A. erythreum DSM $8599^{\mathrm{T}}$ and A. fastidiosum DSM $10552^{\mathrm{T}}$. Hybridization signals were detected with the DIG luminescence detection kit (Roche) and Lumi-Film (Roche) according to the manufacturer's instructions. For quantification of individual spots, the image was digitized and analysed by using ZERO-DSCAN software (Scanalytics). PCR amplification of almost-complete 16S rRNA genes, purification of PCR products and subsequent sequencing analysis were performed according to Brinkhoff \& Muyzer (1997). The sequence of strain $\mathrm{T}^{\mathrm{T}}$ was compared with similar sequences of reference organisms by BLAST search (Altschul et al., 1997). Phylogenetic analysis was performed with the ARB software package (Ludwig et al., 2002). For tree calculation, only sequences with more than $1300 \mathrm{bp}$ were considered. A phylogenetic tree was constructed using neighbour-joining and maximum-likelihood analyses. Alignment positions at which less than $50 \%$ of the sequences of the entire set of data had the same residues were excluded from the calculations to prevent uncertain alignments within highly variable positions of the $16 \mathrm{~S}$ rRNA genes, which cause mistakes in tree topology.

Major phenotypic properties that differentiate strain $\mathrm{T}^{\mathrm{T}}$ from related taxa are summarized in Table 1. Strain $\mathrm{T} 2^{\mathrm{T}}$ is a Gram-positive, non-motile, rod-shaped bacterium. No flagella, pili or other appendages were observed (Fig. 1a, b). This morphology remained constant irrespective of cell

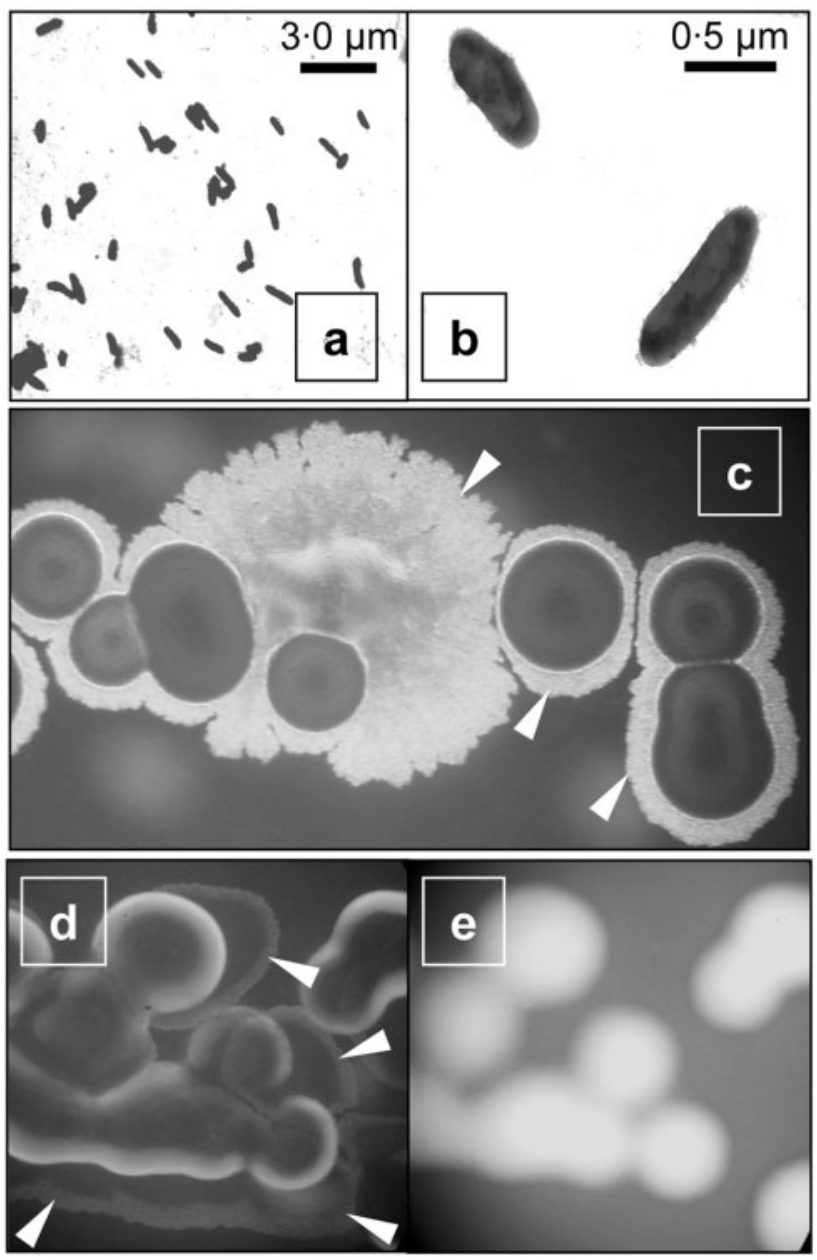

Fig. 1. Morphological features of Aeromicrobium marinum $\mathrm{T}^{\top}{ }^{\top}$. $(a, b)$ Transmission electron micrographs of negatively stained cells of a 10-day-old culture of strain $\mathrm{T}^{\top}{ }^{\top}$ grown in $\mathrm{MB}$. (c, e) Colony morphology on MA observed by light and epifluorescence microscopy at a 50-fold magnification. (c) Haloes (marked by arrowheads) of different sizes were generated by each colony. (d) Photograph of colonies with less-contrasted haloes because they were overlaid with a DAPI solution $\left(10 \mu \mathrm{g} \mathrm{ml}^{-1}\right)$. (e) Photograph of DAPI-stained colonies from the same microscopic field as in (d). 
age. No spores were produced. Colonies were ivory and $0.5-1.0 \mathrm{~mm}$ in diameter, circular and convex. Diffuse haloes of different sizes were observed around the colonies with a microscope (Fig. 1c). The haloes could not be stained with DAPI, indicating that they did not consist of bacterial cells (compare Fig. 1d, e). Treatment with Coomassie blue and Alcian Blue for detection of proteins or acidic polysaccharides, respectively, led to a weak staining of the haloes by Alcian Blue, indicating that one component of the haloes may be acidic polysaccharides. We assume that exopolysaccharides are excreted to attach to surfaces, as was proposed for other bacteria (Becker, 1996; Gehrke et al., 2001). Surfaces for attachment might be decaying organic material in the water column, for example, algae, since strain $\mathrm{T} 2{ }^{\mathrm{T}}$ is able to utilize mannitol (Table 1). Mannitol is a major component of seaweed (Budavari, 1989) and it is also known to be a compound of algal exudates (Spencer, 1990). Strain $\mathrm{T} 2^{\mathrm{T}}$ is a strictly aerobic and salt-requiring bacterium showing optimal growth in ASW/YPG medium with salt concentrations in the range $6 \cdot 3-107 \%$ and a maximum at $53.5 \%$. The growth rate at $0 \cdot 8 \%$ was significantly lower and no growth was observed when no salts were added. Besides the results shown in Table 1 , strain $\mathrm{T}^{\mathrm{T}}$ showed growth with cellobiose, succinate, fumarate, pyruvate, crotonic acid, 2-oxoglutarate, arginine and glutamic acid as sole sources of carbon and energy. No growth was observed with fructose, xylose, sucrose, maltose, citrate, ethanol, propanol, butanol, pimelic acid, inositol, benzoic acid, nicotinic acid, salicylic acid, asparagine, aspartic acid, cysteine, glutamine, glycine and histidine. In contrast to related organisms, strain $\mathrm{T}^{\mathrm{T}}$ did not hydrolyse starch and casein (Table 1).

The major cellular fatty acids of strain $\mathrm{T} 2^{\mathrm{T}}$ were similar to those of its nearest relatives, A. erythreum DSM $8599^{\mathrm{T}}$ and A. fastidiosum DSM $10552^{\mathrm{T}}$ : hexadecanoic acid $\left(\mathrm{C}_{16: 0}\right.$, palmitic acid), cis-9-octadecenoic acid $\left(\mathrm{C}_{18: 1} \omega 9 c\right.$, oleic acid), 10-methyl octadecanoic acid (10-Me $\mathrm{C}_{18: 0}$, tuberculostearic acid) and 2-hydroxy hexadecanoic acid (2-OH $\mathrm{C}_{16: 0}$, hydroxypalmitic acid). The fatty acid profiles of the Aeromicrobium species can be clearly distinguished from those of their close relatives Nocardioides albus ATCC $27980^{\mathrm{T}}$ and Kribbella sandramycini ATCC $39419^{\mathrm{T}}$, which were characterized by other major fatty acids (compare data in supplementary table in IJSEM Online; http://ijs.sgmjournals. org). The cellular fatty acid profiles clearly distinguish the three Aeromicrobium species from their relatives. It is noteworthy that the major fatty acid tuberculostearic acid (10-methyl octadecanoic acid) was not found to the same extent in any other closely related species within the suborder Propionibacterineae (Schumann et al., 1997; Park et al., 1999). However, it was found in other genera within the order Actinomycetales, i.e. Mycobacterium, Microbispora, Micromonospora, Arthrobacter, Nocardia, certain Streptomyces spp. (Lechevalier, 1977) and Dietzia (Rainey et al., 1995).

Comparison of the almost-complete 16S rRNA gene sequence of strain $\mathrm{T} 2{ }^{\mathrm{T}}$ with sequences from GenBank demonstrated that this strain is the first described marine bacterium affiliated to the family Nocardioidaceae within the order Actinomycetales. The phylogenetic tree shown in Fig. 2

$0 \cdot 10$

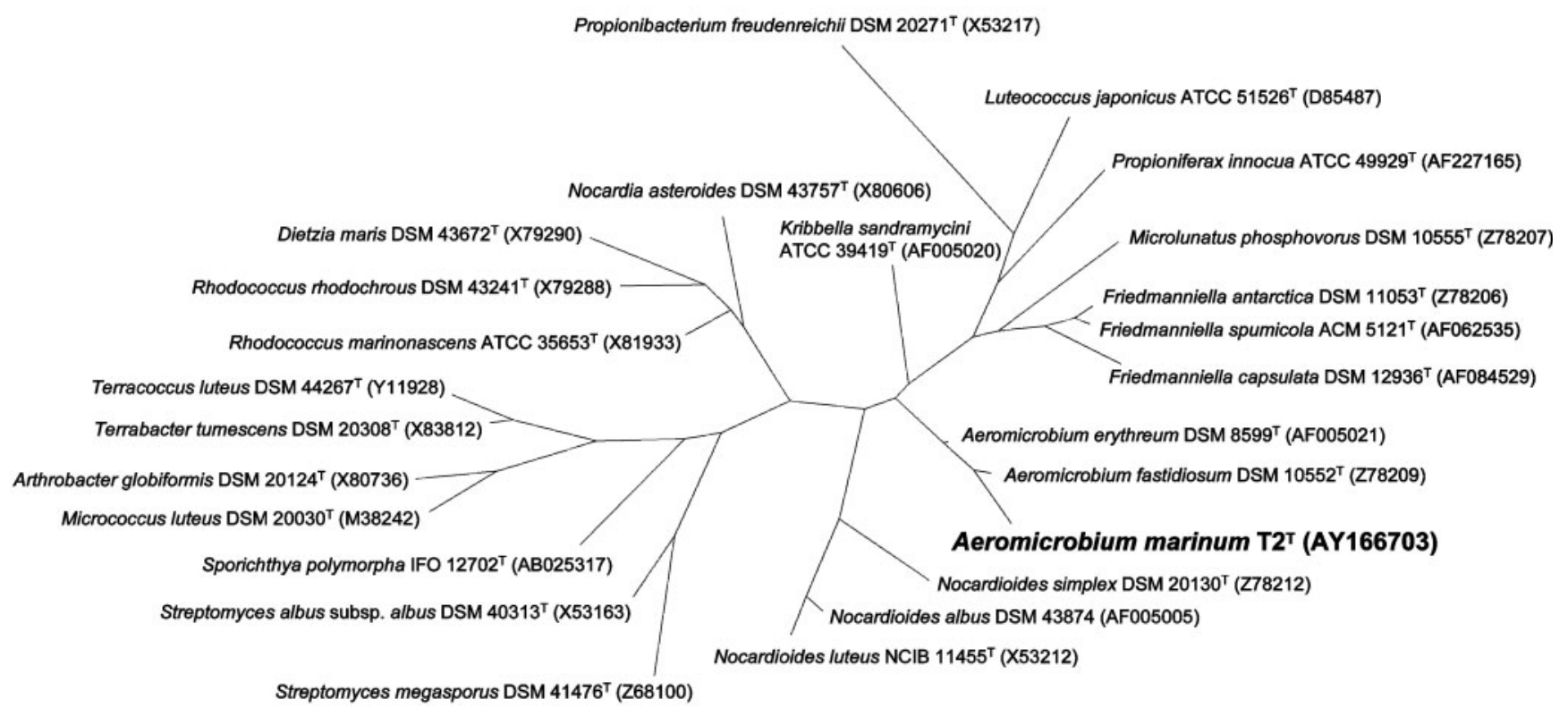

Fig. 2. Unrooted maximum-likelihood tree showing the relationship of Aeromicrobium marinum $\mathrm{T}^{\top}{ }^{\top}$ to members of the order Actinomycetales. Bar, $10 \%$ sequence dissimilarity. 
demonstrates that strain $\mathrm{T} 2{ }^{\mathrm{T}}$ forms a cluster with the two previously described Aeromicrobium species. Similarities between the $16 \mathrm{~S}$ rRNA gene sequence of strain $\mathrm{T}^{\mathrm{T}}$ and those of A. fastidiosum DSM $10552^{\mathrm{T}}$ and A. erythreum DSM $8599^{\mathrm{T}}$ were $97 \cdot 7$ and $97 \cdot 0 \%$, respectively. Other members of the Actinomycetales can be readily distinguished from this branch (Fig. 2). The percentage of DNA-DNA relatedness was $44.4 \%$ for strain $\mathrm{T}^{\mathrm{T}}$ and A. erythreum DSM $8599^{\mathrm{T}}$, and $29 \cdot 1 \%$ for strain $\mathrm{T}^{\mathrm{T}}$ and A. fastidiosum DSM $10552^{\mathrm{T}}$. The reference strains A. erythreum DSM $8599^{\mathrm{T}}$ and A. fastidiosum DSM $10552^{\mathrm{T}}$ exhibited a DNA-DNA relatedness of $30 \cdot 7 \%$. According to Wayne et al. (1987), the phylogenetic definition of a species generally includes strains with more than $70 \%$ DNA-DNA relatedness. Thus, strain $\mathrm{T}_{2}^{\mathrm{T}}$ is clearly distinguishable from the existing Aeromicrobium species.

Two isolates with identical 16S rRNA gene sequences to that of strain $\mathrm{T} 2{ }^{\mathrm{T}}$ were recovered in parallel to $\mathrm{T} 2^{\mathrm{T}}$ from high dilutions $\left(10^{-4}\right)$ of a MPN series inoculated with a water sample from the German Wadden Sea. Assuming that these bacteria were identical or highly related and belong, together with $\mathrm{T}_{2}^{\mathrm{T}}$, to the same species this corresponds to a cell number of $1 \times 10^{4} \mathrm{ml}^{-1}$ of the respective species in the environmental sample. On the basis of the total bacterial cell number of $1 \times 10^{6} \mathrm{ml}^{-1}$ in the original water sample, the MPN results indicate an abundance of $1 \%$ of this species within the bacterial community. To confirm this result, we determined the amount of PCR-generated 16S rRNA gene fragments of strain $\mathrm{T} 2{ }^{\mathrm{T}}$ amplified from the complete natural bacterial community, by dot-blot analysis (Bruns et al., 2002). Tests with the addition of $\sim 100$ - to 500 -fold excess of genomic DNA of the natural community prior to PCR and hybridization analysis showed no interference with the detection of strain $\mathrm{T}^{\mathrm{T}}$ DNA from a pure culture. The intensities of the hybridization signals for strain $\mathrm{T} 2{ }^{\mathrm{T}}$ alone or in combination with the natural community remained similar (compare first and second lane in Fig. 3). Some cross-hybridization was observed with DNA from A. erythreum DSM $8599^{\mathrm{T}}$; however, the intensity of the hybridization signal was only $10 \%$ of that obtained with the same concentration of DNA of strain $\mathrm{T}^{\mathrm{T}}$ (Fig. 3). DNA of A. fastidiosum DSM $10552^{\mathrm{T}}$ gave only very faint hybridization signals (data not shown). This is probably due to nine non-homologous bases within the 16S rRNA gene sequence of $A$. fastidiosum DSM $10552^{\mathrm{T}}$ versus only six non-homologous bases within the sequence of $A$. erythreum DSM $8599^{\mathrm{T}}$ when aligned with the probe sequence. The weak signals obtained with A. erythreum DSM $8599^{\mathrm{T}}$ and A. fastidiosum DSM $10552^{\mathrm{T}}$ also indicate the specificity of the probe and the hybridization conditions developed for the detection of strain $\mathrm{T} 2^{\mathrm{T}}$. Based on the results of our dotblot procedure, genomic DNA of strain $\mathrm{T} 2{ }^{\mathrm{T}}$ and possibly of very closely related strains represents $\leqslant 1 \%$ of the total genomic DNA of the natural community (Fig. 3). These results are consistent with those of the MPN counts and indicate a high abundance $(\sim 1 \%)$ of these bacteria in the natural pelagic community. High amounts of Gram-positive bacteria may result from wash-in events of terrestrial bacteria, as has been discussed previously (Goodfellow \& Haynes, 1984). However, the fact that strain $\mathrm{T}_{2}^{\mathrm{T}}$ is an obligately salt-requiring bacterium and shows its optimal growth at sea water salinities gives striking evidence for its indigenous abundance in a marine habitat, as demonstrated

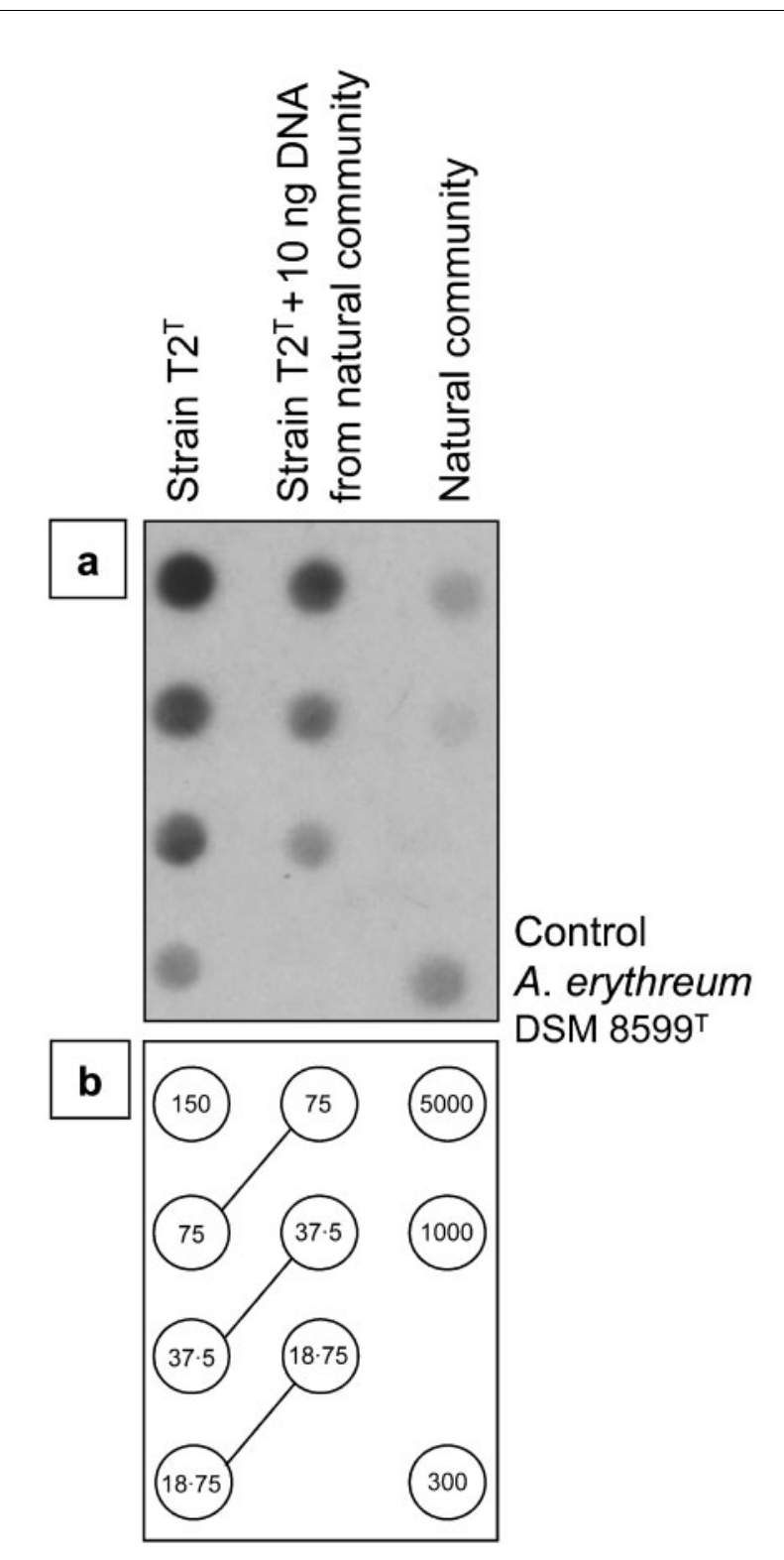

Fig. 3. Quantification of $16 \mathrm{~S}$ rRNA gene fragments of Aeromicrobium marinum $\mathrm{T} 2^{\top}$ in the natural pelagic community of the German Wadden Sea by dot-blot hybridization. (a) Digitized image of an exposed Lumi-Film. (b) The different amounts of genomic template DNA used for PCR amplification are given in picograms. Different concentrations of template DNA of strain $T 2^{T}$ served as standards. As a control for a preferential amplification, DNA of strain $T 2^{\top}$ was mixed with a constant concentration (10 ng) of template DNA from the natural community. 
for other marine Gram-positive bacteria (Jensen et al., 1991; Jensen \& Fenical, 1995).

\section{Description of Aeromicrobium marinum sp. nov.}

Aeromicrobium marinum (ma.ri' num. L. neut. adj. marinum of the sea, marine).

Aerobic. Cells are Gram-positive, non-motile rods that are $0 \cdot 7-1 \cdot 3 \mu \mathrm{m}$ long and $0 \cdot 3-0 \cdot 5 \mu \mathrm{m}$ wide. Ivory-coloured colonies are $0.5-1.0 \mathrm{~mm}$ in diameter and are characterized by a diffuse halo. Grows between 4 and $35^{\circ} \mathrm{C}$, with optimum growth at $25^{\circ} \mathrm{C}$. Growth occurs between $\mathrm{pH} 5.5$ and 9.5, with optimum growth at $\mathrm{pH} 7 \cdot 0-8 \cdot 5$. The optimal salinity for growth is $53.5 \%$; growth is possible between 0.8 and $107 \%$. Catalase-positive and oxidase-negative. Does not reduce nitrate. Grows with the carbon sources trehalose, cellobiose, crotonic acid, 2-oxoglutarate, succinate, fumarate, mannitol, pyruvate, arginine and glutamic acid. Unable to hydrolyse starch, cellulose, lipids, chitin and casein. Contains LL-diaminopimelic acid as the diamino acid in the cell-wall peptidoglycan. The major menaquinone is MK-9 $\left(\mathrm{H}_{4}\right)$. The cellular fatty acids are predominantly hexadecanoic acid (palmitic acid), cis-9-octadecenoic acid (oleic acid), 10-methyl octadecanoic acid (tuberculostearic acid) and 2-hydroxy hexadecanoic acid (hydroxypalmitic acid).

The type strain is $\mathrm{T}^{\mathrm{T}}\left(=\mathrm{DSM} 15272^{\mathrm{T}}=\mathrm{LMG} 21768^{\mathrm{T}}\right)$. The $\mathrm{G}+\mathrm{C}$ content of its DNA is $70 \cdot 6 \mathrm{~mol} \%$. Isolated from surface waters of the German Wadden Sea.

\section{Acknowledgements}

We thank Heike Rütters for fatty acid analysis and Andrea Schlingloff for $16 \mathrm{~S}$ rRNA gene sequencing.

\section{References}

Altschul, S. F., Madden, T. L., Schaffer, A. A., Zhang, J., Zhang, Z., Miller, W. \& Lipman, D. J. (1997). Gapped BLAST and PSI-BLAST: a new generation of protein database search programs. Nucleic Acids Res 25, 3389-3402.

Balch, W. E., Fox, G. E., Magrum, L. J., Woese, C. R. \& Wolfe, R. S. (1979). Methanogens: reevaluation of a unique biological group. Microbiol Rev 43, 260-296.

Becker, K. (1996). Exopolysaccharide production and attachment strength of bacteria and diatoms on substrates with different surface tensions. Microb Ecol 32, 23-33.

Brinkhoff, T. \& Muyzer, G. (1997). Increased species diversity and extended habitat range of sulfur-oxidizing Thiomicrospira spp. Appl Environ Microbiol 63, 3789-3796.

Brosius, J., Dull, T. J., Sleeter, D. D. \& Noller, H. F. (1981). Gene organization and primary structure of ribosomal RNA operon from Escherichia coli. J Mol Biol 148, 107-127.

Bruns, A., Cypionka, H. \& Overmann, J. (2002). Cyclic AMP and acyl homoserine lactones increase the cultivation efficiency of heterotrophic bacteria from the central Baltic Sea. Appl Environ Microbiol 68, 3978-3987.

Budavari, S. (1989). The Merck Index. Rathway, NJ: Merck.
Bull, A. T., Ward, A. C. \& Goodfellow, M. (2000). Search and discovery strategies for biotechnology: the paradigm shift. Microbiol Mol Biol Rev 64, 573-606.

Cashion, P., Holder-Franklin, M. A., McCully, J. \& Franklin, M. (1977). A rapid method for the base ratio determination of bacterial DNA. Anal Biochem 81, 461-466.

Cole, R. M. \& Popkin, T. J. (1981). Electron microscopy. In Manual of Methods for General Bacteriology, pp. 34-51. Edited by P. Gerhardt \& others. Washington, DC: American Society for Microbiology.

Collins, M. D. \& Stackebrandt, E. (1989). Molecular taxonomic studies on some LL-diaminopimelic acid-containing coryneforms from herbage: description of Nocardioides fastidiosa sp. nov. FEMS Microbiol Lett 57, 289-294.

Crump, B. C., Baross, J. A. \& Simenstad, C. A. (1998). Dominance of particle-attached bacteria in the Columbia River estuary, USA. Aquat Microb Ecol 14, 7-18.

De Ley, J., Cattoir, H. \& Reynaerts, A. (1970). Quantitative measurement of DNA hybridization from renaturation rates. Eur $J$ Biochem 12, 133-142.

Escara, J. F. \& Hutton, J. R. (1980). Thermal stability and renaturation of DNA in dimethyl sulfoxide solutions: acceleration of the renaturation rate. Biopolymers 19, 1315-1327.

Fuhrman, J. A., McCallum, K. \& Davis, A. A. (1993). Phylogenetic diversity of subsurface marine microbial communities from the Atlantic and Pacific Oceans. Appl Environ Microbiol 59, 1294-1302. Garrity, G. M. \& Holt, J. G. (2001). The road map to the manual. In Bergey's Manual of Systematic Bacteriology, 2nd edn, vol. 1, pp. 119166. Edited by D. R. Boone \& R. W. Castenholz. New York: Springer. Gehrke, T., Hallmann, R., Kinzler, K. \& Sand, W. (2001). The EPS of Acidithiobacillus ferrooxidans - a model for structure-function relationships of attached bacteria and their physiology. Water Sci Technol 43, 159-167.

Goodfellow, M. \& Haynes, J. A. (1984). Actinomycetes in marine sediments. In Biological, Biochemical and Biomedical Aspects of Actinomycetes, pp. 453-472. Edited by L. Ortiz-Ortiz, L. F. Bojalil \& V. Yakoleff. London: Academic Press.

Groth, I., Schumann, P., Weiss, N., Martin, K. \& Rainey, F. A. (1996), Agrococcus jenensis gen. nov., sp. nov., a new genus of actinomycetes with diaminobutyric acid in the cell wall. Int J Syst Bacteriol 46, 234-239.

Hasegawa, T., Takizawa, M. \& Tanida, S. (1983). A rapid analysis for chemical grouping of aerobic actinomycetes. J Gen Appl Microbiol 29, 319-322.

Helmke, E. \& Weyland, H. (1984). Rhodococcus marinonascens sp. nov., an actinomycete from the sea. Int J Syst Bacteriol 34, 127-138.

Huss, V. A. R., Festl, H. \& Schleifer, K. H. (1983). Studies on the spectrometric determination of DNA hybridization from renaturation rates. J Syst Appl Microbiol 4, 184-192.

Jahnke, K.-D. (1992). Basic computer program for evaluation of spectroscopic DNA renaturation data from GILFORD System 2600 spectrometer on $\mathrm{PC} / \mathrm{XT} / \mathrm{AT}$ type personal computer. J Microbiol Methods 15, 61-73.

Jensen, P. R. \& Fenical, W. (1995). The relative abundance and seawater requirements of Gram-positive bacteria in near-shore tropical marine samples. Microb Ecol 29, 249-257.

Jensen, P. R., Dwight, R. \& Fenical, W. (1991). Distribution of actinomycetes in near-shore tropical marine sediments. Appl Environ Microbiol 57, 1102-1108.

Lechevalier, M. P. (1977). Lipids in bacterial taxonomy - a taxonomist's view. CRC Crit Rev Microbiol 5, 109-210.

Levring, T. (1946). Some culture experiments with Ulva and artificial sea water. K Fysiogr Sallsk Lund Forh 16, 45-56. 
Ludwig, W., Strunk, O., Westram, R. \& 29 other authors (2002). ARB: a software environment for sequence data (http://www.arb-home.de/). Mesbah, M., Premachandran, U. \& Whitman, W. B. (1989). Precise measurement of the $\mathrm{G}+\mathrm{C}$ content of deoxyribonucleic acid by highperformance liquid chromatography. Int J Syst Bacteriol 39, 159-167.

Miller, E. S., Woese, C. R. \& Brenner, S. (1991). Description of the erythromycin-producing bacterium Arthrobacter sp. strain NRRL B-3381 as Aeromicrobium erythreum gen. nov., sp. nov. Int J Syst Bacteriol 41, 363-368.

Mincer, T. J., Jensen, P. R., Kauffman, C. A. \& Fenical, W. (2002). Widespread and persistent populations of a major new marine actinomycete taxon in ocean sediments. Appl Environ Microbiol 68, 5005-5011.

Moran, M. A., Rutherford, L. T. \& Hodson, R. E. (1995). Evidence for indigenous Streptomyces populations in a marine environment determined with a $16 \mathrm{~S}$ rRNA probe. Appl Environ Microbiol 61, 3695-3700.

Okazaki, T. \& Okami, Y. (1976). Studies on actinomycetes isolated from shallow sea and their antibiotic substances. In Actinomycetes, the Boundary Microorganisms, pp. 123-161. Edited by T. Ari. Tokyo: Toppan.

Ortigosa, M., Garay, E. \& Pujalte, M. J. (1997). Gram-positive bacteria of marine origin: a numerical taxonomic study on Mediterranean isolates. Microbiologia 13, 453-462.

Park, Y.-H., Yoon, J.-H., Shin, Y. K., Suzuki, K.-i., Kudo, T., Seino, A., Kim, H.-J., Lee, J.-S. \& Lee, S. T. (1999). Classification of 'Nocardioides fulvus' IFO 14399 and Nocardioides sp. ATCC 39419 in Kribbella gen. nov., as Kribbella flavida sp. nov. and Kribbella sandramycini sp. nov. Int J Syst Bacteriol 49, 743-752.

Prauser, H. (1989). Genus Nocardioides Prauser 1976, 61 ${ }^{\mathrm{AL}}$. In Bergey's Manual of Systematic Bacteriology, vol. 2, pp. 1481-1485. Edited by P. H. A. Sneath, N. S. Mair, M. E. Sharpe \& J. G. Holt. Baltimore: Williams \& Wilkins.

Rainey, F. A., Klatte, S., Kroppenstedt, R. M. \& Stackebrandt, E. (1995). Dietzia, a new genus including Dietzia maris comb. nov., formerly Rhodococcus maris. Int J Syst Bacteriol 45, 32-36.

Rappé, M. S., Kemp, P. F. \& Giovannoni, S. J. (1997). Phylogenetic diversity of marine coastal picoplankton $16 \mathrm{~S}$ rRNA genes cloned from the continental shelf off Cape Hatteras, North Carolina. Limnol Oceanogr 42, 811-826.

Rappé, M. S., Gordon, D. A., Vergin, K. L. \& Giovannoni, S. J. (1999). Phylogeny of Actinobacteria small subunit (SSU) rRNA gene clones recovered from marine bacterioplankton. Syst Appl Microbiol 22, 106-112.

Rhuland, L. E., Work, E., Denman, R. F. \& Hoare, D. S. (1955). The behavior of the isomers of alpha, epsilon-diaminopimelic acid on paper chromatography. J Am Chem Soc 77, 4844-4846.

Sass, A., Rütters, H., Cypionka, H. \& Sass, H. (2002). Desulfobulbus mediterraneus sp. nov., a sulfate-reducing bacterium growing on mono- and disaccharides. Arch Microbiol 177, 468-474.

Schumann, P., Prauser, H., Rainey, F. A., Stackebrandt, E. \& Hirsch, P. (1997). Friedmanniella antarctica gen. nov., sp. nov., an LL-diaminopimelic acid-containing actinomycete from Antarctic sandstone. Int J Syst Bacteriol 47, 278-283.

Smibert, R. M. \& Krieg, N. R. (1994). Phenotypic characterization. In Methods for General and Molecular Bacteriology, pp. 607-654. Edited by P. Gerhardt, R. G. E. Murray, W. A. Wood \& N. R. Krieg. Washington, DC: American Society for Microbiology.

Spencer, K. G. (1990). Lipids and polyols from microalgae. In Algae and Human Affairs, pp. 248-249. Edited by C. A. Lembi. Cambridge: Cambridge University Press.

Takeuchi, M. \& Hatano, K. (1998). Proposal of six new species in the genus Microbacterium and transfer of Flavobacterium marinotypicum ZoBell and Upham to the genus Microbacterium as Microbacterium maritypicum comb. nov. Int J Syst Bacteriol 48, 973-982.

Takizawa, M., Colwell, R. \& Hill, R. (1993). Isolation and diversity of Actinomycetes in the Chesapeake Bay. Appl Environ Microbiol 59, 997-1002.

Tamaoka, J. \& Komagata, K. (1984). Determination of DNA base composition by reversed-phase high-performance liquid chromatography. FEMS Microbiol Lett 25, 125-128.

Urakawa, H., Kita-Tsukamoto, K. \& Ohwada, K. (1999). Microbial diversity in marine sediments from Sagami Bay and Tokyo Bay, Japan, as determined by $16 \mathrm{~S}$ rRNA gene analysis. Microbiology 145, 3305-3315.

Wayne, L. G., Brenner, D. J., Colwell, R. R. \& 9 other authors (1987). International Committee on Systematic Bacteriology. Report of the ad hoc committee on reconciliation of approaches to bacterial systematics. Int J Syst Bacteriol 37, 463-464.

Widdel, F. \& Bak, F. (1992). Gram-negative mesophilic sulphatereducing bacteria. In The Prokaryotes, 2nd edn, pp. 3353-3378. Edited by A. Balows, H. G. Trüper, M. Dworkin, W. Harder \& K.-H. Schleifer. New York: Springer-Verlag. 